\title{
An Economics Analysis: Trend \& Performance of Agriculture Production in Haryana
}

\author{
Dr Rajinder Godara Associate professor LPU \\ Bal krishan Research Scholar LPU
}

\begin{abstract}
The Agriculture sector is the mainstay role of Indian's Economy \& livelihood through the generate of employment in the agriculture sector. With the passage of time the Agriculture \& Allied Sector is continuously declining because of a cause of land fragmented day by day. Due to the land fragmented but ours' dependency on the industrial sector as well as the services sector. In the agriculture sector in 2017-18 of the workforce, 50 percent of people engagement depends on the agriculture sector. Further agriculture sector contribution 17-18 percent of the total GDP (Gross domestic product) of national income. In Haryana state agriculture contribution is about 14.5 percent to its gross domestic product (GDP) while providing employment 51 percent of the workforce engaged in agriculture. Further, about $75 \%$ of the area is irrigated, through tube Wells and an extensive system of canals. About 2/3rd of the State has assured irrigation, most suited for a rice-wheat production system, whereas rain-fed lands around 1/5th are most suited for rapeseed \& mustard, pearl millet, cluster bean cultivation, agro-forestry, and arid-horticulture. Methodology Statistical Techniques and Tools: The secondary data published from Haryana statistical Abstract, Economic The survey, Ministry of Agriculture and Farmers' Welfare, published Research papers in the journal, and agriculture reports and so on. To compute the growth behavior of trends and performance of agriculture production in Haryana farm area, yield, production and income, the exponential function will be fitted. Review of Literature, Problem increasing the productivity in Haryana. Improved agriculture Productivity
\end{abstract}

\section{Conclusion:}

Govt adoptions of crops of diversification in the present scenario of Haryana $\mathbf{1 5}$ percent cover area for horticulture production. The govt targeted in 2030 triple production in horticulture crops and to the maximum is to cover the area for horticulture crops. Because of the adoption of crop diversification farmers' income increase, as well as production, will increase.

\section{INTRODUCTION}

The Agriculture sector is the mainstay role of Indian's Economy \& livelihood through the generate of employment in the agriculture sector. With the passage of time the Agriculture \& Allied Sector is continuously declining because of a cause of land fragmented day by day. Due to the land fragmented but ours' dependency on the industrial sector as well as the services sector. In the agriculture sector in 2017-18 of the workforce, 50 percent of people engagement depends on the agriculture sector. Further agriculture sector contribution 17-18 percent of the total GDP (Gross domestic product) of national income. In Haryana state agriculture contribution is about 14.5 percent to its gross domestic product (GDP) while providing employment 51 percent of the workforce engaged in agriculture. The agriculture sector is the contribution of Indian economy much higher than the world's average 6.4 percent while Haryana constitute 1.5 percent cover of India's area. Haryana is among the top ten producers of food grains and stands at sixth place with a total production of 16.38 Million Tones from an area of 4.47 Million Hectares. Further total food grains produced in the state, contribution of wheat and rice was 11.3 and 4.15 Million Tons respectively in 2017-18. Haryana is the 4th largest producer of wheat in a country with approximately 12 percent of total wheat production while the state stands at 10th place in total rice production as well as coarse cereals, jowar, bajra are also produced in the state. (Source: Ministry of Agriculture and Farmers' Welfare). Haryana state is situated in north India with its capital of Chandigarh. It is established on 1 Nov 1966 as newly created $17^{\text {th }}$ the state of India. It is surrounded by the Uttar Pradesh in east Punjab in the west Himachal Pradesh in the north and Rajasthan in the south. Haryana is a land leaked state in northern India, is located between 27.39 to 30.35 degrees North latitude and between 74.28 degrees and 77.36-degrees longitude. The altitude of Haryana varies between 700 to 3600 feet 200 meters to 1200 meters above sea level. Haryana's basic crops increase because of the reason to increase production while to the adoption of the appreciation. Haryana's major crops Rabi crops include these crops are wheat, tobacco, gram, linseed, rapeseed, and mustard, sown in late October or early November and harvested in March and April month. Approximately $86 \%$ of the area is arable, and $96 \%$ is cultivated. Further, about $75 \%$ of the area is irrigated, through tube Wells and an extensive system of canals. About 2/3rd of the State has assured irrigation, most suited for a rice-wheat production system, whereas rain-fed lands around $1 / 5$ th are most suited for rapeseed \& mustard, pearl millet, cluster bean cultivation, agro-forestry, and arid-horticulture. On the other hand, the agriculture sector depends on many Allied sectors like dairying, poultry, fishery, arid horticulture, mushroom farming, beekeeping, agro forestry have great potential. In Haryana, agricultural marketing is a very important role to increase the farmers' income because of the farmer's indebtedness to sell their agriculture product in spot place. Agriculture's marketing is malpractice in India while the farmers do not get remunerative prices or procurement prices on the spot. Further to overcome the 
malpractice the govt set up the CACP in 1965 because of the main motives the govt wants the peasants to get a fair price of their production to produce by farmers. In the year 2018 govt to stop of the malpractices in agricultural marketing to start the E-NAM mandi through the E-NAM mandi farmers get a remunerative price of their production. According to the E-Nam Scheme State has been connected with three NAM (National Agricultural Market) scheme Further to make system agricultural marketing of produce smooth, transparent and farmer/trade man-friendly.

Methodology Statistical Techniques and Tools: The secondary data published from Haryana statistical Abstract, Economic The survey, Ministry of Agriculture and Farmers' Welfare, published Research papers in the journal, and agriculture reports and so on. To compute the growth behavior of trends and performance of agriculture production in Haryana farm area, yield, production and income, the exponential function will be fitted. Following the form of least the square exponential function will be used to compute the compound growth rates.

\section{REVIEW OF LITERATURE}

Tripathy (1996) analyzed the trends in Rice production after the green revolution in Orissa for the time period starting from $1970-71$ to $1989-90$. It was found that there was remained 1.43 percent significant growth per annum in the state. It was also stated by the results that positive results have remained in case of the yield of rice in all districts of the state. However, the productivity of rice appeared to be stagnant in Kalahandi, Keonjhar and Sundarghrh districts.

Chand and Birthal (1997) found that pesticides use in Indian agriculture had witnessed a very fast growth after 1957-58. In the first decade of the green revolution, the growth in pesticide use was faster than the output growth. However, the growth rate in output was remained to be much faster than the growth in pesticide use during the post green revolution era. A comparison of pesticides used in agriculture in various countries revealed that its use in India was neither excessive nor indiscriminate.

Samui et al. (2005) visualized that the adaptation of advanced technology led to a significant rise in sugarcane yield and production during the extended green revolution era (1970-80). But in the post green revolution phase (1980-2001) had a decrease in the yield of sugarcane played a negative role in sugarcane production. Sugarcane production declined in Maharashtra because the area brought under this crop was rather non-traditional viz. These areas had limited water resources and limited of other factors such as shallow depth of rooting zone and poor nutrient status. That's why productivity growth could not be increased.

Sadeesh et al. (2006) studied that the total production growth of oilseeds was found to increase this was because the implementation of a technology mission focused on oilseeds. Significant positive growth in the production of total oilseeds was shown by Karnataka, Madhya Pradesh and Maharashtra. Productivity also increased India as a whole showed significant positive growth in production and productivity.

Kumar and Singh (2014) found the growth behaviour of the area, yield, and production of sugarcane crop for the time period starting from 2000-01 to 2009-10. The results were obtained for the district and state level in Haryana. The main factors that caused the trends were also identified in the same study. According to the different agro-climatic conditions, Haryana has been divided into the eastern and western zone. There were emerged negative trends in relation to the area under sugarcane irrespective district, region and state level. Almost the same results were obtained in case of the production of sugarcane barring only Bhiwani and Karnal. Most of the district of Haryana witnessed positive growth rates for the yield of sugarcane. It was also indicated that the growth rate for the area under sugarcane has remained higher in comparison to the growth of output of the crop in point in almost all districts of Haryana.

Tripathy (1996) analyzed the trends in Rice production after the green revolution in Orissa for the time period starting from $1970-71$ to $1989-90$. It was found that there was remained 1.43 percent significant growth per annum in the state. It was also stated by the results that positive results have remained in case of the yield of rice in all districts of the state. However, the productivity of rice appeared to be stagnant in Kalahandi, Keonjhar and Sundarghrh districts.

Chand and Birthal (1997) found that pesticides use in Indian agriculture had witnessed a very fast growth after 1957-58. In the first decade of the green revolution, the growth in pesticide use was faster than the output growth. However, the growth rate in output was remained to be much faster than the growth in pesticide use during the post green revolution era. A comparison of pesticides used in agriculture in various countries revealed that its use in India was neither excessive nor indiscriminate.

Samui et al. (2005) visualized that the adaptation of advanced technology led to a significant rise in sugarcane yield and production during the extended green revolution era (1970-80). But in the post green revolution phase (1980-2001) had a decrease in the yield of sugarcane played a negative role in sugarcane production. Sugarcane production declined in Maharashtra because the area brought under this crop was rather non-traditional viz. These areas had limited water resources and limited of other factors such as shallow depth of rooting zone and poor nutrient status. That's why productivity growth could not be increased.

Sadeesh et al. (2006) studied that the total production growth of oilseeds was found to increase this was because the implementation of a technology mission focused on oilseeds. Significant positive growth in the production of total oilseeds was shown by Karnataka, Madhya Pradesh 
and Maharashtra. Productivity also increased India as a whole showed significant positive growth in production and productivity.

Kumar and Singh (2014) found the growth behaviour of the area, yield, and production of sugarcane crop for the time period starting from 2000-01 to 2009-10. The results were obtained for the district and state level in Haryana. The main factors that caused the trends were also identified in the same study. According to the different agro-climatic conditions, Haryana has been divided into the eastern and western zone. There were emerged negative trends in relation to the area under sugarcane irrespective district, region and state level. Almost the same results were obtained in case of the production of sugarcane barring only Bhiwani and Karnal. Most of the district of Haryana witnessed positive growth rates for the yield of sugarcane. It was also indicated that the growth rate for the area under sugarcane has remained higher in comparison to the growth of output of the crop in point in almost all districts of Haryana.

\section{Methodology Statistical Techniques and Tools:}

The secondary data published from Haryana statistical Abstract, Economic The survey, Ministry of Agriculture and Farmers' Welfare, published Research papers in the journal, and agriculture reports and so on. To compute the growth behavior of trends and performance of agriculture production in Haryana farm area, yield, production and income, the exponential function will be fitted. Following the form of least the square exponential function will be used to compute the compound growth rates.

\section{Land utilization in Haryana state table}

\begin{tabular}{|c|c|c|c|c|c|c|}
\hline Sr. No. & Particulars & 1993-94 & 1998-99 & 2003-04 & 2008-09 & 2013-14 \\
\hline \multirow[t]{2}{*}{1} & Net area sown & 3513 & 3628 & 3534 & 3576 & 3497 \\
\hline & & $(80.3)$ & $(82.9)$ & $(80.7)$ & $(81.7)$ & $(79.9)$ \\
\hline \multirow[t]{2}{*}{2} & $\begin{array}{c}\text { Area sown more than } \\
\text { once }\end{array}$ & 2302 & 2692 & 2854 & 2924 & 2974 \\
\hline & & $(52.6)$ & $(61.5)$ & $(65.2)$ & $(66.8)$ & $(67.9)$ \\
\hline 3 & Total cropped area & 5815 & 6320 & 6388 & 6500 & 6471 \\
\hline \multirow[t]{2}{*}{4} & Forest & 167 & 115 & 45 & 39 & 35 \\
\hline & & $(3.81)$ & $(2.62)$ & $(1.02)$ & $(0.89)$ & $(0.80)$ \\
\hline \multirow[t]{2}{*}{5} & $\begin{array}{l}\text { Land put to non- } \\
\text { agricultural uses }\end{array}$ & 322 & 350 & 432 & 470 & 537 \\
\hline & & $(7.36)$ & $(8.00)$ & $(9.87)$ & $(10.7)$ & $(12.2)$ \\
\hline \multirow[t]{2}{*}{6} & $\begin{array}{c}\text { Barren and } \\
\text { uncultivable land }\end{array}$ & 91 & 89 & 100 & 103 & 125 \\
\hline & & $(2.08)$ & $(2.03)$ & $(2.28)$ & $(2.35)$ & $(2.85)$ \\
\hline \multirow[t]{2}{*}{7} & Current fallows & 209 & 143 & 192 & 105 & 101 \\
\hline & & $(4.77)$ & $(3.26)$ & $(4.38)$ & $(2.40)$ & $(2.31)$ \\
\hline \multirow[t]{2}{*}{8} & Total area & 4374 & 4374 & 4374 & 4374 & 4374 \\
\hline & & $(100)$ & (100) & (100) & (100) & (100) \\
\hline
\end{tabular}

Note: Figures in parentheses are in percentages except total cropped area as it is more than

Table 1:- Land utilization in Haryana (Area in 000' hectares)

\section{Land Use Pattern in Haryana State}

\begin{tabular}{|c|c|c|c|}
\hline & Total geographical area & Total geographical & percentage \\
\hline 1 & Total geographical area & 4421 & N.A \\
\hline 2 & Reporting area for land utilization & 4371 & 0.92 \\
\hline 3 & Forests & 40 & 13.11 \\
\hline 4 & Not available for cultivation & 373 & 0.69 \\
\hline 5 & Permanent pastures and other grazing land & 12 & 0.28 \\
\hline 6 & Land under Misc.tree crops and groves & 29 & 0.67 \\
\hline 7 & Curturable wasteland & 5 & 0.12 \\
\hline 8 & Fallow lands other than current fallows & 105 & 2.40 \\
\hline 9 & Current fallow & 3576 & 81.81 \\
\hline
\end{tabular}

Table 2

Source; Land use statistics, Ministry of agriculture, GOI, 2008-09 
In this table visualizes the land is acquired for non- agricultural motives because of landholding size operation detached. Do to the land of shrink the infrastructure very rapidly day. Because of the structural changes in our' economy Like the construction of roads, established in industrialization as well as the services sector developed. Many people migration rural to urban areas for accommodation in life because they can get the facility in urban areas. The center govt as well as the state and local govt for the development of land acquired in rural areas Due to many schemes launched like these scheme rural development, Pradhan Mantri Awyas yojana. Further, the Road construction and water resources management as well as to set up big project for the land acquired while land fragmented in large scale

Numbers of area of operational land holding in Haryana 2011(ha.)

\begin{tabular}{|c|c|c|c|c|c|c|c|c|c|}
\hline \multirow{2}{*}{$\begin{array}{c}\text { Size } \\
\text { group }\end{array}$} & \multicolumn{2}{|c|}{ Individual holdings } & \multicolumn{2}{|c|}{ Joint Holding } & \multicolumn{2}{|c|}{ Institutional Hodling } & \multicolumn{2}{|c|}{ Total Holdings } & \multirow{2}{*}{$\begin{array}{c}\text { Avg. Size } \\
\text { (Ha.) }\end{array}$} \\
\hline & No. & Area & No & Area & No & Area & No & Area & \\
\hline $\begin{array}{c}\text { Marginal } \\
<1 \text { ha. }\end{array}$ & 288881 & 132925 & 483400 & 224915 & 5861 & 2635 & 778142 & 360475 & 0.46 \\
\hline $\begin{array}{c}\text { Small 1-2 } \\
\text { ha }\end{array}$ & 108831 & 164083 & 203575 & 295054 & 2412 & 3567 & 314818 & 462704 & 1.47 \\
\hline $\begin{array}{l}\text { Semi- } \\
\text { Medium } \\
\text { 2-4 ha }\end{array}$ & 89273 & 256590 & 192236 & 551277 & 2319 & 6606 & 283828 & 814473 & 2.87 \\
\hline $\begin{array}{l}\text { Medium } \\
\text { 4-10ha }\end{array}$ & 41223 & 237482 & 150427 & 928243 & 3044 & 19708 & 194694 & 118533 & 6.09 \\
\hline $\begin{array}{c}\text { Large } 10 \\
\text { ha+ }\end{array}$ & 2852 & 41620 & 39401 & 655508 & 3576 & 125392 & 45829 & 822520 & 17.95 \\
\hline Total & 531060 & 832700 & 1069039 & 2654997 & 17212 & 157908 & 1617311 & 3645605 & 2.25 \\
\hline
\end{tabular}

Table 3

Source: Director of Census Operations, Haryana

\section{Problem increasing the productivity in Haryana}

- Soil erosion of degradation; One of the major problems to increase the productivity of the production. The soil erosion is increasing day by day many reasons soil degradation to huge the use of fertilizer as well as chemical and pesticide in agriculture sector. Because of the fertilizer and chemical, the water logging problem is arising. To be overcome the soil of erosion we use in organic in agriculture. Not only has the problem in Haryana whiled the other states problems in solid degradation. Punjab is the first state to be crisis the problem of soil erosion.

- Water Crisis problem in Haryana: As the population is increased the agriculture sector pressed because the agricultural commodities demand increased in the market. Further to gain of the profit in agriculture to use of chemicals and pesticides. The agriculture consumed water approximately $80 \%$.while on the other hand farmer's preference in Kharif crop and wheat crops. For the Kharif crops like paddy we need the abundance of water for paddy. Further to overcome the water crisis in Haryana govt to adopt the crop diversification and national horticulture mission. The Haryana's govt suggests the substitution of the paddy we should grow maize. The availability of the good quality of for the irrigation in Haryana in $65 \%$ Further the industrial sector polluted of the water the main polluted water by the cotton industries and leather or marble industries while the Climate Change is a negative effect of the agriculture sector because of the climate change dairy farming and livestock farming faced a critical problem.

\section{Improved agriculture Productivity}

- Strategy the use yielding varieties seeds in the agriculture sector. To be prompted in agriculture sector India adoption the high yielding varieties seeds in because of the use green revolution came in India. Further many other factors responsible for the green revolution hybrid seeds, new technology used in agriculture sector as well as to change the infrastructure and govt policies to increase the tremendous production in the agriculture sector.

- To control the disease: Haryana govt to adoption Pest management disease of the crops. Further the wheat crops yellow rust disease these diseases the major challenge for Haryana in the agriculture sector. To control the disease Haryana to use DSR and CA use technology in the agriculture sector.

- Change in demand; agricultural commodities change in demand pattern day by day the demand an increase in horticulture productivity. The horticulture productivity is the most important role in India. As we compared the other states with Haryana is not a good performance to produce horticulture crops. The Haryana govt should improve horticulture because of the increase in demand in an urban area 
Increased production to face the major problem by farmers

- Size of landholding operational: Farm size holding operational decrease day by day as the population increased the farm size holding fragmented because of the fragmented the small and marginal and semimarginal farmers do not set up the water treatment plant. Further the cost of the cultivation is very high as well as agricultural equipment very high prices because of the marginal farmers and semi- marginal farmers can't purchase because of their production are not increase.

\section{$>$ Lack of adoption of new technology}

New technology equipment like a tractor, harvester, Harro, Zero tiller fertilizer and pesticide cost price very high because of the semi-farmers and the marginal farmer does not an adoption of the new technology. Farmers' friendly small tools and agriculture implements are either not available to the farmers or they are not convinced with their working efficiency, resulting in paying labor charges and increasing the cost of cultivation. Agriculture is the only enterprise where prices are determined by others than the producer. Also, the long chain of middlemen for marketing absorbs the farmers' margin leaving them with minimal profit for their product's Yield gaps between research stations/Field Level Demonstrations and farmers field and lack of knowledge about modern agriculture technologies and environment result in increased cost of cultivation without enhancing their production and hence profits. Farmers lack knowledge of latest technologies and various government schemes, this deficit of information limits their ability to make a profit. Agriculture development for a loan by the central govt

\section{$>$ Kisan credit card introduced}

For agriculture development, the central govt introduces the Kisan card scheme (KCC) in 1998. Haryana stands at 15 th position in issuing $\mathrm{KCC}$, with 2.42 percent of issued $\mathrm{KCC}$ in the country. UP ranks first with approximately 20 percent of the total issued KCC. Of the total 36.41 lakh KCCs issued in the state, 47 percent are issued by commercial banks, 37 percent by cooperative banks and 16 percent by RRBs.

\section{Agriculture insurance scheme}

Centre govt started the agriculture insurance scheme to cover the risk of the farmers. Further, the scheme applies Kharif or wheat crops Haryana state govt implement to cover the risk of Kharif 2004, Haryana is 15th position of the country under the insurance scheme in Haryana 635778 farmers and to cover of the land area 769038.32 hectare land. Maharashtra is the first position of the country to be the maximum cover of the farmers and cover area of a hectare.

\section{CONCLUSION}

Agriculture development and agriculture growth, the govt launched scheme pradhan mantra Fasal Bima yojana," According to this scheme to cover the basic crops in this scheme like paddy, bajra, maize, and cotton know as Kharif crops. On the other hand wheat, barley, gram and mustard in rabi season to cover the crops insurance. Further, soil erosion to use fertilizer pesticides and chemicals in the agriculture sector. To overcome soil degradation govt adopt the organic farming under this scheme 50 acres to cover the land area to use inorganic fertilizers. To be prompt govt start the new scheme," Paramparagat Krishi Vikas Yojana," this scheme insist to use the organic fertilizer and to stop the burring crops of residue while the adoption of automation. Mostly in Haryana's farmer sapling basic crops because of these crops the negative effect of soil fertility as well as water dilution. Govt adoptions of crops of diversification in the present scenario of Haryana 15 percent cover area for horticulture production. The govt targeted in 2030 triple production in horticulture crops and to the maximum is to cover the area for horticulture crops. Because of the adoption of crop diversification farmers' income increase, as well as production, will increase. For the development of horticulture, Haryana govt established the horticulture university in karnal as well as three regional research stations established these stations with the international collaboration global universities. For the sustainable development of agriculture to start seed treatment programmed in actuarial as well as the additional extended coverage in the agriculture sector. Further in agriculture, the marketing problem is a very crucial problem in India, Generally, the farmers do not get a remunerative price of their products in the market. The market situation depends on averaging up or down many factors depends on the market like excess of demand commodities or excess supply of the commodities and includes the profit of charity/tradesman. Govt must be focus to increase the farmer's income and insist on the watershed development program as well as contract farming and adoption of Blanket policy use of betterment for agriculture sector in the future.

\section{REFERENCES}

[1]. Abhey Singh Godara and Usha Poonia (2013) "Impact of Prices on Acreage and Income from Gram in Haryana", volume 2, issue 9 International Journal of Innovative Research and \& Development

[2]. Annesha Mech (2017) An analysis of growth trend, instability and determinants of rice production in Assam, Indian Journal of Agricultural Research., 51 (4) 2017: 355-359

[3]. Badal, P. S. and R. P. Singh (2001) "Technological Change in Maize Production: A Case Study of Bihar", Indian Journal of Agricultural Economics, 56 (2): 211-219. 
[4]. Bhowmick, B. C. and A. U. Ahamed (1993) "Behaviour of Trend and Growth of Area, Production, Productivity and Supply Response of Major Oilseed Crops in Assam", Agricultural Situation in India, XLVIII (1): 3-7.

[5]. Birhanu Ayalew, (2015) "Trends, Growth and Instability of Finger millet Production in Ethiopia" Research Journal of Agriculture and Environmental Management Vol. 4(2), pp. 078-081, February, 2015

[6]. Chand, Ramesh and S. S. Raju (2009) "Instability in Indian Agriculture During Different Phases of Technology and Policy", Indian Journal of Agricultural Economics, 64 (2): 187-207.

[7]. Chandrasekaran, M., S. Varadarajan and K. Chandran (1989) "Temporal Variation in Fertiliser Use for Rice Production in Tamil Nadu", Agricultural Situation in India, XLIV (4): 255-257.

[8]. Dixit, V. K. and J. L. Bhardwas (1990) “The Impact of Tractorisation on Farm Employment in Raipur District of Madhya Pradesh", Agricultural Situation in India, 45 (4): 233-236. 